\title{
Keragaman Gulma, Pertumbuhan dan Hasil Padi Sawah Pada Sistem Tanam dan Penyiangan yang Berbeda
}

\author{
Weed Diversity, Growth and Yield of Lowland Rice in Different Planting and \\ Weeding Systems \\ Jenal Mutakin \\ Program Studi Agroteknologi, Fakultas Pertanian, Universitas Garut, Jl. Raya \\ Samarang No.52A, Tarogong Kaler, Kabupaten Garut, Jawa Barat 44151 \\ Email :
}

\begin{abstract}
ABSTRAK
Penelitian ini bertujuan untuk mengetahui keragaman gulma, pertumbuhan dan hasil padi sawah pada sistem tanam dan penyiangan yang berbeda. Penelitian menggunakan metode eksperimen rancangan petak terpisah (RPT) pola faktorial. Hasil penelitian menunjukkan bahwa Terdapat perbedaan gulma penting pada masing masing sistem tanam dan waktu penyiangan umur 15, 30 dan 45 HST. Pada sistem organik adalah Sphenoclea zeylanica Gaertn dengan INP berturut-turut sebagai berikut ; $(101,02 \%, 120,90 \%$ dan $63,73 \%)$; pada sistem tanam TOT dan sistem tanam konvensional gulma penting adalah Ludwigia hyssopifolia (G.Don) Exell dengan INP sistem tanam TOT $(116,67 \%, 119,97 \%$ dan 108,85\%); dan sistem tanam konvensional $(116,67 \%, 136,54 \%$ dan 127,44\%). Indeks keragaman (H') semua sistem tanam dan umur penyiangan berkisar antara 0,39- 0,61 (rendah). Sistem tanam berinteraksi dengan penyiangan terhadap tinggi tanaman pada umur 40 dan 60 HST serta jumlah anakan produktif, sedangkan pada tinggi tanaman dan jumlah anakan umur $20 \mathrm{HST}$, jumlah anakan umur $40 \mathrm{HST}$ dan hasil gabah per plot tidak terjadi interakasi. Pada umur 40 dan 60 HST kombinasi sistem tanam organik dan penyiangan satu kali (15 HST) berpengaruh terhadap rata-rata tanaman yang lebih tinggi, Sedangkan terhadap jumlah anakan produktif rata-rata tertinggi ditunjukkan pada kombinasi sistem tanam dengan penyiangan dua kali yaitu pada umur penyiangan 15 dan $30 \mathrm{HST}$.
\end{abstract}

Kata kunci: gulma, padi sawah, penyiangan, sistem tanam, dan organik

\begin{abstract}
This study aims to determine the diversity of weeds, growth and yield of rice in different planting and weeding systems. The study used a factorial separate plot design (RPT) experimental method. The results showed that there were important weed differences in each planting system and weeding time of 15, 30 and 45 HST. In the organic system are Sphenoclea zeylanica Gaertn with successive INPs as follows; (101.02\%, 120.90\% and 63.73\%); in TOT planting systems and conventional weed planting systems important are Ludwigia hyssopifolia (G.Don) Exell with INP TOT planting systems (116.67\%, 119.97\% and 108.85\%); and conventional planting systems $(116.67 \%, 136.54 \%$ and 127.44\%). The diversity
\end{abstract}


index $\left(H^{\prime}\right)$ of all planting systems and weeding ages ranged from 0.39 to 0.61 (low). Planting systems interact with weeding of plant height at the age of 40 and 60 HST and the number of productive tillers, whereas at plant height and number of tillers $20 \mathrm{HST}$, the number of tillers at $40 \mathrm{HST}$ and grain yield per plot does not occur. At the age of 40 and 60 HST the combination of organic planting systems and one-time weeding (15 HST) influences the average plant height, while the highest average number of productive tillers is shown in a combination of planting systems with weeding twice, namely at weeding age 15 and $30 \mathrm{HST}$.

Keywords: weeds, lowland rice, weeding, planting systems, and organic

\section{PENDAHULUAN}

Padi merupakan tanaman penghasil beras sebagai makanan pokok sebagian besar penduduk Indonesia. Dengan peningkatan jumlah penduduk Indonesia sebesar $1,36 \%$ pertahun, maka diperkirakan pada tahun 2020 dibutuhkan beras sebesar 35,97 juta ton dengan asumsi konsumsi $137 \mathrm{~kg}$ per kapita (Irianto, 2009). Produksi padi di Indonesia tahun 2017 mencapai 5,3 ton/ha dengan produksi mencapai 7.603.187 ton (Kementrian Pertanian, 2017).

Tanaman padi dapat dibudidayakan dengan menggunakan tiga sistem tanam yaitu sistem tanam organik, tanpa olah tanah (TOT) dan sistem tanam konvensional. Ketiga sistem tanam tersebut memberikan pengaruh yang berbeda terhadap pertumbuhan gulma pada pertanaman padi. Indeks keanekaragaman jenis gulma padi sawah anorganik lebih tinggi dibanding gulma padi sawah organik (Krebs, 1989), namun apabila dilihat total jumlah individunya gulma pada sistem organik lebih banyak dari gulma pada sistem anorganik. Hal ini disebabkan sawah organik memiliki ketersediaan unsur hara tanah yang mudah diserap oleh tanaman dan struktur tanah lebih baik, sedangkan sawah anorganik banyak menggunakan pupuk dan zat kimia sintetis sehingga menyebabkan lingkungan tumbuh rusak dan banyak kehilangan unsur kesuburan tanah (Pusat Pendidikan Lingkungan Hidup, 2010).

Gulma jika tidak dikendalikan akan menimbulkan persaingan dengan tanaman yang dibudidayakan, sehingga menyebabkan terganggunya pertumbuhan dan hasil tanaman. Penurunan hasil padi akibat gulma berbanding lurus dengan kerapatan gulma per satuan luas tertentu, seperti Echinocloa crusgalli yang dapat menurunkan hasil tanaman padi sebesar $57 \%$ per meter persegi. Manurung dkk., 
(1988) menyatakan bahwa untuk mengendalikan keberadaan gulma yang ada pada pertanaman padi dapat dilakukan dengan berbagai teknik pengendalian, baik secara fisik, mekanik maupun secara kimia.

Salahsatu faktor yang mempengaruhi besarnya persaingan dalam pertanaman padi sawah adalah kepadatan gulma yang ada di sekitar pertanaman. Semakin tinggi kepadatan gulma, semakin menurunkan hasil tanaman padi (Sukman dan Yakup, 2002). Menurut Tjitroesoedirdjo dkk. (1984), menjelaskan bahwa semakin tinggi tingkat pertumbuhan dan kerapatan gulma, maka tingkat persaingan padi dengan gulma terhadap faktor tumbuh semakin tinggi pula, terutama terhadap perolehan hara dari dalam tanah.

Penekanan terhadap pertumbuhan gulma diantaranya dapat dilakukan dengan penyiangan. Perbedaan waktu penyiangan menyebabkan perbedaan terhadap lama tumbuh gulma bersama tanaman. Gulma yang tumbuh lebih lama besama tanaman akan menyebabkan penekanan gulma terhadap tanaman akan semakin tinggi, sehingga pertumbuhan tanaman akan semakin terhambat. Jamilah (2013) membuktikan bahwa penyiangan pada sistem tanam konvensional jumlah anakan terbanyak dijumpai pada waktu penyiangan gulma 20 hari yaitu 22,22 anakan dan terendah pada penyiangan gulma umur 40 hari yaitu 21,47 anakan. Tujuan penelitian ini adalah untuk pengetahui keragaman gulma, pertumbuhan dan hasil padi pada sistem tanam dan penyiangan yang berbeda.

\section{METODE PEENLITIAN}

Penelitian dilaksanakan pada bulan Oktober 2017 sampai bulan Februari 2018 pada lahan sawah milik petani di Desa Depok, Kecamatan Cisompet, Kabupaten Garut berada pada ketinggian 110 mdpl dengan tipe curah hujan B. Bahan yang digunakan dalam penelitian ini meliputi benih padi varietas Ciherang pupuk organik, pupuk an organik (pupuk buatan), Mikro Organisme Lokal (MOL), dan herbisida jenis glifosat $42 \%$ dan alat yang digunakan meliputi, peralatan budidaya, ajir, mistar, spidol waterproof, kuadrat ukuran 0,5 m x 0,5 m, tali rapia, alat tulis, kantong plastik, label, oven, amplop coklat, neraca analitik, dan kamera. 
Penelitian ini menggunakan metode eksperimen dengan Rancangan Petak Terpisah (RPT) pola faktorial 3x3 dan diulang sebanyak tiga kali. Faktor pertama adalah Sistem tanam $(S)$ yaitu $S_{1}$ : Sistem Tanam Organik, $S_{2}$ : Sistem Tanam Tanpa Olah Tanah (TOT), dan $\mathrm{S}_{3}$ : Sistem Tanam Konvensional. Dan sub plot adalah Penyiangan $(\mathrm{P})$ yaitu : $\mathrm{P}_{0}$ : Penyiangan 1 kali (15 HST), $\mathrm{P}_{2}$ : Penyiangan 2 kali (15 dan $30 \mathrm{HST}$ ) dan $\mathrm{P}_{3}$ : Penyiangan 3 kali (15, 30 dan 45 HST). Pengambilan sampel gulma dilakukan satu hari sebelum penyiangan dengan menggunakan kuadrat $50 \mathrm{cmx} 50 \mathrm{~cm}$ yang diletakkan pada setiap plot perlakuan. Gulma yang diperoleh kemudian dihitung jumlah dan jenisnya, serta bobot kering perspesiesnya, kemudian dilakukan analisis keragaman gulma dilakukan dengan menghitung Nilai Penting Gulma (NP) dengan perhitungan menurut Chaves dan Bhandari (1982) yaitu Nilai Penting (NP) = Kerapatan relatif + Frekuensi relatif, Indeks Keanekaragaman H' menurut Shannon-Wiener (Indeks Diversitas) H' = $\sum$ (pi) (ln pi), dengan kriteria: Nilai Indeks Keanekaragaman antara 0 - 2 (rendah), Nilai Indeks Keanekaragaman antara 2 - 3 (sedang) dan Nilai Indeks Keanekaragaman antara > 3 (tinggi). Analisis Pertumbuhan dan Hasil padi meliputi; tinggi tanaman, Jumlah Anakan, Jumlah Anakan Produktif dan Bobot Gabah Per Plot Data yang diperoleh kemudian diuji menggunakan uji ANOVA dengan model linier menurut (Gasperzs, 2006), sebagai berikut : Yijk $=\mu+$ $\mathrm{Kk}+\mathrm{Bi}+\delta \mathrm{ik}+\mathrm{Mj}+(\mathrm{BM}) \mathrm{ij}+\mathrm{eijk}$

\section{HASIL DAN PEMBAHASAN}

\section{Keanekaragaman Gulma}

Gulma yang ditemukan dan hasil perhitungan Indeks Nilai Penting (INP) pada sistem tanam dan waktu penyiangan yang berbeda (Tabel 1) menunjukkan bahwa pada umur 15 HST ditemukan 4 jenis gulma pada sistem tanam organik, sistem tanam TOT maupun Konvensional yaitu Ludwigia hyssopifolia (G.Don) Exell, Eleusine indica (L.) Gaertn, Cyperus iria L. dan Sphenoclea zeylanica Gaertn dengan total individu 49 pada sistem tanam organik, 60 pada sistem tanam TOT dan 40 pada sistem tanam konvensional. Pada umur 30 HST gulma yang ditemukan pada sistem tanam organik 3 jenis yaitu Ludwigia hyssopifolia (G.Don) Exell, Cyperus iria L. dan Sphenoclea zeylanica Gaertn dengan jumlah 195 
individu, sistem tanam TOT terdapat 5 jenis gulma yaitu Ludwigia hyssopifolia (G.Don) Exell, Eleusine indica L. Gaertn, Cyperus iria L., Sphenoclea zeylanica Gaertn dan Monochoria vaginalis dengan jumlah 53 individu, dan pada sistem tanam konvensional ditemukan 4 jenis gulma yaitu Ludwigia hyssopifolia (G.Don) Exell, Fimbristylis miliacea, Cyperus iria L, dengan jumlah 52 individu. Dan pada penyiangan umur 45 HST ditemukan 5 jenis gulma yang sama dengan jumlah individu baik sistem tanam organik, sistem tanam TOT maupun sistem tanam konvensional yaitu Ludwigia hyssopifolia (G.Don) Exell, Eleusine indica (L.) Gaertn, Fimbristylis miliacea, Cyperus iria L. dan Sphenoclea zeylanica Gaertn. Total individu jenis gulma yang ditemukan pada sistem tanam organik adalah 204 individu, pada sistem tanam TOT adalah 131 individu dan sistem tanam.

Tabel 1. Nilai Penting Gulma pada Kombinasi Sistem Tanam dan Penyiangan Umur 15, 30 dan 45 HST

\begin{tabular}{llllllllll}
\hline & \multicolumn{8}{c}{ Indeks Nilai Penting (INP) } \\
\hline Nama gulma & \multicolumn{4}{c}{ 15HST } & \multicolumn{3}{c}{ 30 HST } & \multicolumn{4}{c}{45 HST } \\
\hline & S1 & S2 & S3 & S1 & S2 & S3 & S1 & S2
\end{tabular}

$\underline{\mathrm{S} 3}$

\begin{tabular}{lllllllll}
\hline Ludwigia hyssopifolia & 74,11 & 116,67 & 116,67 & 58,88 & 119,97 & 136,54 & 73,53 & 108,85
\end{tabular}

127,44

(G.Don) Exell

$\begin{array}{lllllllll}\text { Eleusine indica (L.) Gaert } & 8,29 & 12,22 & 18,33 & - & 6,63 & - & 22,79 & 44,07\end{array}$

9,64

Fimbristylis mileacea

18,71

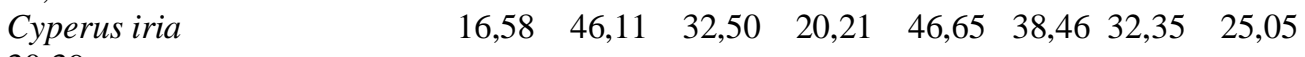

30,39

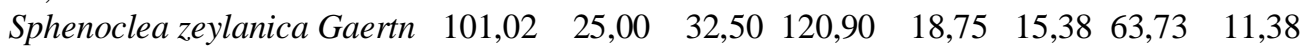

13,83

Monochoria vaginalis

\begin{tabular}{lllllllll}
\hline Total $\sum$ Jenis & 4 & 4 & 4 & 3 & 5 & 4 & 5 & 5
\end{tabular}

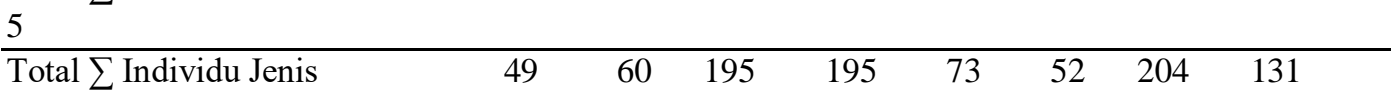
147

Keterangan: S1 Sistem Tanam Organik, S2 Sisten Tanam TOT dan S3 Sistem tanam Konvensional

konvensional adalah 147 individu.

Perbedaan jenis gulma yang tumbuh pada areal pertanaman padi dengan sistem tanam organik, sistem tanam TOT dan sistem tanam konvensional terjadi karena dipengaruhi oleh faktor lingkungan yang mendukung terhadap syarat tumbuh gulma tersebut, seperti kesuburan tanah, sistem pengairan dan cara budidaya. Gulma Ludwigia hyssopifolia (G.Don) Exell merupakan gulma yang 
ada disetiap sistem tanam dan waktu penyiangan padi. B.P.Caton dkk., (2011) mengemukakan bahwa Ludwigia hyssopifolia (G.Don) Exell senang tumbuh pada dataran rendah, pendapat lain dari Soerjani dkk., (1987), mengemukakan bahwa gulma Ludwigia hyssopifolia (G.Don) Exell merupakan gulma air yang penting pada tanaman padi sawah dan pada tingkat kepadatan yang tinggi dapat menyaingi tanaman.

Nilai penting gulma tertinggi pada penyiangan umur 15 HST pada sistem tanam organik adalah Sphenoclea zeylanica Gaertn (101,02\%), pada pada sistem tanam TOT dan sistem tanam konvensional gulma tertinggi adalah Ludwigia hyssopifolia (G.Don) Exell dengan nilai penting pada pada sistem tanam TOT $(116,67 \%)$ dan sistem tanam konvensional $(116,67 \%)$, sedangkan yang terendah adalah Eleusine indica (L.) Gaertn pada semua sistem tanam. Sistem tanam organik $(8,29 \%)$, sistem tanam TOT $(12,22 \%)$ dan sistem tanam konvensional $(18,33 \%)$, begitu pula pada penyiangan umur 30 HST sistem tanam organik memiliki nilai penting tertingginya adalah Sphenoclea zeylanica Gaertn $(120,90 \%)$, sistem tanam TOT dan sistem tanam konvensional nilai penting tertinggi adalah Ludwigia hyssopifolia (G.Don) Exell, dengan nilai penting $(119,97 \%)$ dan $(136,54 \%)$. Nilai penting terendah pada penyiangan umur 30 HST sistem tanam organik adalah Cyperus iria (20,21\%), sistem tanam TOT adalah Monochoria vaginalis $(8 \%)$ dan pada sistem tanam konvensional adalah Fimbristylis mileacea $(9,62 \%)$. Sedangkan pada penyiangan umur 45 HST nilai penting tertinggi pada semua sistem tanam adalah Ludwigia hyssopifolia (G.Don) Exell dengan nilai penting sistem tanam organik adalah $(73,53 \%)$, sistem tanam TOT (108,85\%), dan konvensional $(127,44 \%)$.

Komunitas gulma dikatakan memiliki keanekaragaman jenis yang tinggi jika komunitas itu disusun oleh banyak jenis, sebaliknya komunitas gulma dikatakan memiliki keanekaragaman jenis yang rendah apabila komunitas tersebut disusun oleh jenis yang sedikit sama halnya dengan yang diungkapkan Afrianti dkk., (2014) bahwa kemerataan jenis dianggap maksimum jika semua jenis memiliki jumlah individu yang sama. Kemerataan jenis terjadi jika terdapat beberapa jenis hidup bersama dalam satu habitat. 
Indeks Keanekaragaman (H') Shannon-Wiener diperoleh dengan parameter kemelimpahan jenis dan proporsi kemelimpahan masing-masing jenis. Kriteria yang digunakan untuk menafsirkan formula tersebut adalah apabila nilai Indeks Keanekaragaman (H') antara 0-2 (rendah), 2-3 (sedang) dan > 3 (tinggi).

Hasil analisis indeks keanekaragaman ( $\left.\mathrm{H}^{\prime}\right)$ disajikan dalam Tabel 2, menunjukkan bahwa pada umur 15, 30, dan 45 HST baik sistem tanam organik, TOT maupun konvensional memiliki indeks keanekaragaman kurang dari satu atau memiliki keanekaragaman yang rendah.

Tabel 2. Indeks Keanekaragaman (H') Umur 15 HST, 30 HST dan 45 HST dengan Sistem Tanam Organik, TOT dan Konvensional

\begin{tabular}{|c|c|c|c|c|c|c|c|c|}
\hline \multirow[b]{2}{*}{ Nama gulma } & \multicolumn{8}{|c|}{ Indeks Keragaman (H') } \\
\hline & & \multicolumn{2}{|c|}{ 15HST } & \multicolumn{2}{|c|}{$30 \mathrm{HST}$} & \multicolumn{3}{|c|}{$45 \mathrm{HST}$} \\
\hline S3 & S1 & S2 & S3 & S1 & S2 & S3 & S1 & S2 \\
\hline $\begin{array}{l}\text { Ludwigia hyssopifolia } \\
0,12 \\
\text { (G.Don) Exell }\end{array}$ & 0,16 & 0,14 & 0,14 & 0,16 & 0,13 & 0,11 & 0,16 & 0,14 \\
\hline $\begin{array}{l}\text { Eleusine indica (L.) Gaert } \\
0,06\end{array}$ & 0,06 & 0,07 & 0,10 & - & 0,05 & - & 0,11 & 0,14 \\
\hline $\begin{array}{l}\text { Fimbristylis mileacea } \\
0,10\end{array}$ & - & - & - & - & - & 0,06 & 0,05 & 0,07 \\
\hline $\begin{array}{l}\text { Cyperus iria } \\
0,12\end{array}$ & 0,09 & 0,15 & 0,13 & 0,10 & 0,15 & 0,14 & 0,13 & 0,11 \\
\hline $\begin{array}{l}\text { Sphenoclea zeylanica Gaertn } \\
0,08\end{array}$ & 0,15 & 0,11 & 0,13 & 0,13 & 0,10 & 0,09 & 0,16 & 0,07 \\
\hline Monochoria vaginalis & - & - & - & - & 0,06 & - & - & - \\
\hline $\begin{array}{l}\text { Total } \sum \text { Jenis } \\
0,49\end{array}$ & 0,46 & 0,47 & 0,49 & 0,39 & 0,48 & 0,40 & 0,61 & 0,54 \\
\hline
\end{tabular}

Keterangan : Kriteria $0-2$ (Rendah), $2-3$ (Sedang), > 3 (Tinggi)

Nilai indeks keragaman sistem tanam organik $(0,46)$, TOT $(0,47)$ dan konvensional $(0,49)$ tidak berbeda dengan umur 15 HST pada umur 30 HST indek keanekaragaman yang didapat kurang dari satu yaitu pada sistem tanam organik $(0,39)$, TOT $(0,48)$ dan konvensional $(0,40)$, begitu pula pada umur 45 HST indeks keanekaragaman gulma yang didapat kurang dari satu yaitu pada sistem tanam organik $(0,61)$, TOT $(0,54)$ dan konvensional $(0,49)$.

Hal ini berarti bahwa keanekaragaman gulma disemua sistem tanam, baik pada sistem tanam organik, TOT ataupun konvensional tergolong keanekaragaman rendah, ditandai dengan adanya jenis gulma yang mendominasi. Lingkungan dengan indeks keanekaragaman rendah dapat dikatakan labil, karena 
didominasi oleh jenis tertentu dan ada jenis gulma tertentu yang mendesak kehidupan gulma yang lainnya (Odum, 1971).

\section{Tinggi Tanaman}

Berdasarkan hasil analisis ragam menunjukkan sistem tanam tidak berinteraksi dengan penyiangan terhadap tinggi tanaman pada umur 20 HST (Tabel 3.), namun secara mandiri terjadi perbedaan yang nyata. Angka rata-rata pada Tabel 3 menunjukkan bahwa sistem tanam organik mampu memacu pertumbuhan tinggi tanaman yang lebih tinggi dibandingkan sistem tanam TOT dan Konvensional. Sedangkan pada perlakuan penyiangan rata-tara tinggi tanaman tidak menunjukkan perbedaan yang nyata.

Keadaan tersebut menggambarkan bahwa sistem tanam organik dapat memberikan kesuburan tanah yang lebih baik dibandingkan sistem tanam TOT dan konvensional. Pupuk organik yang diberikan pada sistem organik mampu memperbaiki lingkungan tumbuh tanaman seperti kesuburan fisik, kimia dan biologi tanah. Hal ini sesuai pernyataan Sitompul (1995) bahwa tinggi tanaman merupakan indikator pertumbuhan yang digunakan untuk mengukur pengaruh lingkungan atau perlakuan, karena tinggi tanaman merupakan ukuran pertumbuhan yang paling mudah dilihat.

Tabel 3. Pengaruh sistem tanam dan penyiang terhadap tinggi tanaman Umur 20 HST

\begin{tabular}{lrl}
\hline \multicolumn{1}{r}{ Perlakuan } & Tinggi Tanaman \\
\hline Sistem Tanam & & \\
Organik (S1) & 50,60 & $\mathrm{~b}$ \\
TOT (S2) & 31,35 & $\mathrm{a}$ \\
Konvensional (S3) & 35,72 & $\mathrm{a}$ \\
Penyiangan & & \\
15 HST (P0) & 38,19 a \\
15 dan 30 HST (P1) & 40,88 a \\
15, 30 dan 45 HST (P2) & 38,59 a \\
\hline Keterangan : Angka rata-rata yang diikuti huruf yang sama & pada setiap kolom
\end{tabular}

Keterangan : Angka rata-rata yang diikuti huruf yang sama pada setiap kolom tidak berbeda nyata pada taraf $5 \%$ berdasarkan Uji Batas Nyata Terkecil

Hasil analisis data tinggi tanaman pada umur 40 dan 60 HST menunjukkan bahwa sistem tanam beriteraksi dengan penyiangan (Tabel 4 dan 5). Pada umur 40 
dan 60 HST, kombinasi perlakuan sistem organik dengan penyiangan satu kali pada umur 15 HST menunjukkan rata-rata tinggi tanaman tertinggi, dan rata-rata tinggi tanam terendah terjadi pada sistem tanam TOT dengan penyiangan 15 HST. yang berbeda nyata jika dibandingkan dengan kombinasi perlakuan yang lainnya.

Tabel 4. Interaksi Antara Sistem Tanam dan Penyiangan Terhadap Tinggi Tanaman Umur 40 HST

\begin{tabular}{crrrrrr}
\hline Sistem & \multicolumn{5}{c}{ Penyiangan } \\
\cline { 2 - 5 } Tanam & 15 HST (P0) & 15 dan 30 HST (P1) & 15,30 dan 45 HST (P2) \\
\hline Organik (S1) & 94,89 & $\mathrm{~b}$ & 82,24 & $\mathrm{a}$ & 84,71 & $\mathrm{a}$ \\
& $\mathrm{B}$ & & $\mathrm{B}$ & & $\mathrm{B}$ & \\
TOT (S2) & 54,80 & $\mathrm{a}$ & 61,90 & $\mathrm{c}$ & 60,67 & $\mathrm{~b}$ \\
Konvensional & $\mathrm{A}$ & & $\mathrm{A}$ & & $\mathrm{A}$ & \\
(S3) & 57,22 & $\mathrm{a}$ & 64,11 & $\mathrm{~b}$ & 61,63 & $\mathrm{a}$ \\
\hline Keterangan & $\mathrm{A}$ & & $\mathrm{A}$ & & $\mathrm{A}$ & \\
\end{tabular}

Keterangan : Angka rata-rata yang diikuti huruf kecil yang sama pada arah vertikal dan huruf besar yang sama arah horizontal, tidak berbeda nyata berdasarkan Uji Batas Nyata Terkecil pada taraf nyata 5\%

Keadaan ini menggambarkan bahwa sistem organik lahannya lebih subur, pada lingkungan tumbuh yang subur pertumbuhan tanaman akan diikuti dengan pertumbuhan gulma banyak, sehingga pada kondisi unsur hara yang mencukupi dengan populasi tumbuhan yang lebih banyak, maka pertubuhan akan diarahkan ke bagian tinggi tanaman (etiolasi) sehingga, tanaman yang disiang satu kali pada umur 15 HST menjadi lebih tinggi dibadingkan dengan yang siang dua kali dan tiga kali.

Tabel 5. Interaksi Antara Sistem Tanam dan Penyiangan Terhadap Tinggi Tanaman Umur 60 HST

\begin{tabular}{|c|c|c|c|c|}
\hline \multirow{2}{*}{$\begin{array}{l}\text { Sistem } \\
\text { Tanam }\end{array}$} & \multicolumn{4}{|c|}{ Penyiangan } \\
\hline & $15 \mathrm{HST}(\mathrm{P} 0)$ & 15 dan 30 HST (P1) & \multicolumn{2}{|c|}{$\begin{array}{c}15,30 \text { dan } 45 \text { HST } \\
(\mathrm{P} 2)\end{array}$} \\
\hline \multirow{2}{*}{ Organik (S1) } & $111,18 \quad b$ & $95,96 \quad \mathrm{a}$ & 99,13 & $\mathrm{a}$ \\
\hline & $\mathrm{C}$ & A & $\mathrm{C}$ & \\
\hline \multirow{2}{*}{ TOT (S2) } & 73,05 a & $83,32 \quad b$ & 74,17 & $\mathrm{a}$ \\
\hline & $\mathrm{A}$ & A & A & \\
\hline \multirow{2}{*}{$\begin{array}{c}\text { Konvensional } \\
\text { (S3) }\end{array}$} & $96,00 \quad a$ & 97,73 a & 97,59 & $\mathrm{a}$ \\
\hline & $\mathrm{B}$ & A & $\mathrm{B}$ & \\
\hline
\end{tabular}


Keterangan : Angka rata-rata yang diikuti huruf kecil yang sama pada arah vertikal dan huruf besar yang sama arah horizontal, tidak berbeda nyata berdasarkan Uji Batas Nyata Terkecil pada taraf nyata 5\%

\section{Jumlah Anakan}

Hasil analisis ragam jumlah anakan pada umur 20 dan 40 HST disajikan pada Tabel 6 dan 7. Angka rata-rata yang tersaji pada tabel 6 dan 7 menunjukkan bahwa pada umur 20 dan 40 HST sistem tanam tidak berinteraksi dengan penyiangan terhadap jumlah anakan, namun secara mandiri terjadi perbedaan yang nyata. Dari tabel 6 dan 7 terlihat bahwa pada umur 20 dan 40 HST jumlah anakan tertinggi ditunjukkan oleh sistem tanam konvensial yang tidak berbeda nyata dengan sistem organik, sedangkan pada perlakuan penyiangan perbedaan rata-rata jumlah anakan haya terjadi pada umur 40 HST, sedangkan pada umur 20 HST menunjukkan tidak berbeda nyata.

Tabel 6. Pengaruh Sistem Tanam dan Penyiangan Terhadap Jumlah Anakan Pada Umur 20 HST

\begin{tabular}{lcc}
\hline Perlakuan & \multicolumn{2}{c}{ Tinggi Tanaman } \\
\hline Sistem Tanam & & \\
Organik (S1) & 10,40 & $\mathrm{~b}$ \\
TOT (S2) & 6,11 & $\mathrm{a}$ \\
Konvensional (S3) & 10,80 & $\mathrm{~b}$ \\
\hline Penyiangan & & \\
15 HST (P0) & 7,51 & $\mathrm{a}$ \\
15 dan 30 HST (P1) & 10,11 & $\mathrm{a}$ \\
15,30 dan 45 HST (P2) & 9,64 & $\mathrm{a}$ \\
\hline Ke
\end{tabular}

Keterangan : Angka rata-rata yang diikuti huruf yang sama pada setiap kolom tidak berbeda nyata pada taraf $5 \%$ berdasarkan Uji Batas Nyata Terkecil

Keadaan ini menggambarkan bahwa perbedaan umur benih dan jumlah yang ditanam pada sistem tanam organik dan konvensional tidak menyebabkan perbedaan jumlah anakan yang tumbuh pada setiap rumpun. Pada sistem organik hanya ditanam satu benih perlubang dan umur lebih muda, sedangkan pada konvensional dan TOT benih ditanam lebih banyak dan umur lebih tua. Hal ini disebabkan pada sistem organik, waktu pindah tanam bagian-bagian tanaman tidak terganggu, baik waktu pencabutan maupun waktu penanamannya, Sehingga tanaman tidak mengalami stagnasi pada pertumbuhuannya. Ismunadji dkk., (1988), menyatakkan bahwa jumlah anakan ditentukan oleh radiasi matahari, hara mineral serta budidaya tanaman itu sendiri. 
Pada umur 40 HST perlakuan penyiangan tiga kali pada umur 15, 30 dan 45 HST menunjukkan rata-rata tertinggi taberbeda nyata dengan penyiangan satu kali umur 15 HST. Hal ini terjadi pada penyiangan 3 kali keberadaan gulma menjadi lebih sedikit, sehingga pada lingkungan yang subur dengan tingkat kompetisi yang lebih rendah pertumbuhan tanaman akan lebih leluasa termasuk pertumbuhan jumlah anakan.

Tabel . 7 Pengaruh Sistem Tanam dan Penyiangan Terhadap Jumlah Anakan Pada Umur 40 HST

\begin{tabular}{llc}
\hline Perlakuan & \multicolumn{2}{c}{ Tinggi Tanaman } \\
\hline Sistem Tanam & & \\
Organik (S1) & 20,98 & $\mathrm{~b}$ \\
TOT (S2) & 18,91 & $\mathrm{a}$ \\
Konvensional (S3) & 22,31 & $\mathrm{~b}$ \\
\hline Penyiangan & & \\
15 HST (P0) & 15,04 & $\mathrm{a}$ \\
15 dan 30 HST (P1) & 22,75 & $\mathrm{~b}$ \\
15,30 dan 45 HST (P2) & 24,40 & $\mathrm{~b}$ \\
\hline
\end{tabular}

Keterangan : Angka rata-rata yang diikuti huruf yang sama pada setiap kolom tidak berbeda nyata pada taraf $5 \%$ berdasarkan Uji Batas Nyata Terkecil

Jatmiko dkk., (2002) mengatakan bahwa gulma berinteraksi dengan tanaman melalui persaingan untuk mendapatkan satu atau lebih faktor tumbuh yang terbatas, seperti cahaya, hara dan air. Menurut Fadli dkk., (2013) penyiangan pada padi harus dilakukan dengan cepat untuk mengindari tanaman menjadi kerdil karena terjadinya perebutan unsur hara.

Jumlah Anakan Produktif

Tabel 8. Interaksi Sistem Tanam dan Penyiangan Terhadap Jumlah Anakan Produktif

\begin{tabular}{|c|c|c|c|c|c|c|}
\hline \multirow{2}{*}{$\begin{array}{l}\text { Sistem } \\
\text { Tanam }\end{array}$} & \multicolumn{6}{|c|}{ Penyiangan } \\
\hline & 15 HST (P0) & & $\mathrm{HST}(\mathrm{P} 1)$ & & 45 HST & \\
\hline \multirow{2}{*}{ Organik (S1) } & 13,33 & $\mathrm{a}$ & 23,53 & $\mathrm{c}$ & 19,00 & $\mathrm{~b}$ \\
\hline & $\mathrm{A}$ & & & & A & \\
\hline \multirow{2}{*}{ TOT (S2) } & 20,87 & $\mathrm{~b}$ & 17,33 & $\mathrm{a}$ & 18,93 & $\mathrm{a}$ \\
\hline & A & & & & A & \\
\hline \multirow{2}{*}{$\begin{array}{l}\text { Konvensional } \\
\text { (S3) }\end{array}$} & 17,93 & $\mathrm{a}$ & 18,13 & $\mathrm{a}$ & 18,33 & $\mathrm{a}$ \\
\hline & $\mathrm{A}$ & \multicolumn{2}{|c|}{ A } & \multicolumn{3}{|c|}{ A } \\
\hline \multicolumn{7}{|c|}{$\begin{aligned} & \text { Keterangan : } \text { Keterangan : Angka rata-rata yang diikuti huruf kecil yang sama } \\
& \text { pada arah vertikal dan huruf besar yang sama arah horizontal, tidak } \\
& \text { berbeda nyata berdasarkan Uji Batas Nyata Terkecil pada taraf } \\
& \text { nyata 5\% }\end{aligned}$} \\
\hline
\end{tabular}


Hasil analisis data anakan produktif disajikan dalam Tabel 8. Berdasarkan hasil analisis ragam menunjukkan bahwa sistem tanam berinteraksi dengan penyiangan terhadap jumlah anakan produktif. Kombinasi sistem tanam organik dengan penyiangan dua kali yaitu 15 dan 30 memberikan rata-rata jumlah anakan produktif tertinggi dan terendah ditunjukkan pula oleh sistem tanam organik pada penyiangan satu kali 15 HST yang berbeda nyata dengan kombinasi lainnya. Karim dan Suhartatik (2009), menyatakan bahwa tidak semua mata tunas akan tumbuh menjadi anakan karena hal itu ditentukan oleh jarak tanam, radiasi, hara mineral dan budidaya.

\section{Bobot Gabah Per plot}

Hasil analisis bobot gabah per plot disajikan dalam Tabel 9. Perlakuan Sistem tanam tidak berpengaruh nyata terhadap bobot gabah per plot baik secara mandiri maupun interaksinya, namun perlakuan penyiangan menunjukkan pengaruh nya nyata. Dari tabel terlihat bahwa penyiangan dua kali yaitu umur 15 dan 30 HST menunjukkan rata-rata tertinggi yang berbeda nyata dengan taraf perlakuan lainnya. Norman, dkk., (1984) menyatakan bahwa, hasil padi ditentukan baik secara genetik maupun oleh berbagai faktor lingkungan (iklim, hara/tanah dan air). Hal ini sejalan dengan pendapat Nurhidayat (2011), bahwa produktivitas dan mutu hasil tanaman padi yang banyak ditentukan pada fase pengisian dan pematangan biji atau buah sangat dipengaruhi oleh berbagai unsur iklim dan cuaca, terutama suhu udara.

Tabel 9. Pengaruh Antara Sistem Tanam dan Penyiangan Terhadap Bobot Per Plot

\begin{tabular}{|c|c|}
\hline Perlakuan & Bobot GPK plot \\
\hline \multicolumn{2}{|l|}{ Sistem Tanam } \\
\hline Organik (S1) & $137,40 \quad \mathrm{a}$ \\
\hline TOT (S2) & $127,20 \quad \mathrm{a}$ \\
\hline Konvensional (S3) & $140,00 \quad \mathrm{a}$ \\
\hline \multicolumn{2}{|l|}{ Penyiangan } \\
\hline $15 \operatorname{HST}(\mathrm{P} 0)$ & $124,80 \quad \mathrm{a}$ \\
\hline 15 dan 30 HST (P1) & $147,73 \quad b$ \\
\hline 15, 30 dan 45 HST (P2) & $136,07 \quad \mathrm{a}$ \\
\hline
\end{tabular}

Keterangan : Angka rata-rata yang diikuti huruf yang sama pada setiap kolom tidak berbeda nyata pada taraf $5 \%$ berdasarkan Uji Batas Nyata Terkecil 


\section{KESIMPULAN}

a. Terdapat perbedaan gulma penting pada masing masing sistem tanam dan waktu penyiangan umur 15, 30 dan 45 HST. Pada sistem organik adalah Sphenoclea zeylanica Gaertn dengan INP berturut-turut sebagai berikut ; $(101,02 \%, 120,90 \%$ dan 63,73\%); pada sistem tanam TOT dan sistem tanam konvensional gulma penting adalah Ludwigia hyssopifolia (G.Don) Exell dengan INP sistem tanam TOT $(116,67 \%, 119,97 \%$ dan 108,85\%); dan sistem tanam konvensional $(116,67 \%, 136,54 \%$ dan $127,44 \%)$. Indeks keragaman (H') semua sistem tanam dan umur penyiangan berkisar antara 0,39- 0,61 (rendah)

b. Sistem tanam berinteraksi dengan penyiangan terhadap tinggi tanaman pada umur 40 dan 60 HST serta jumlah anakan produktif, sedangkan pada tinggi tanaman dan jumlah anakan umur 20 HST, jumlah anakan umur 40 HST dan hasil gabah per plot tidak terjadi interakasi. Pada umur 40 dan 60 HST kombinasi sistem tanam organik dan penyiangan satu kali (15 HST) berpengaruh terhadap rata-rata tanaman yang lebih tinggi, Sedangkan terhadap jumlah anakan produktif rata-rata tertinggi ditunjukkan pada kombinasi sistem tanam dengan penyiangan dua kali yaitu pada umur penyiangan 15 dan 30 HST.

\section{DAFTAR PUSTAKA}

Afrianti,I., Yolanda, R., Purnama,\& Anthonius, A. (2014). Analisis Vegetasi Gulma Pada Perkebunan Kelapa Sawit (Elaeis quinensis jaqc)di Desa Suka Maju Kecamatan Rambah dan Kabupaten Rukon. Media Jurnal Biologi.

Caton, B. P., Mortimer M., Hill, J. E. dan Johnson, D. E. 2011. Panduan Lapang Praktis Gulma Padi di Asia. Edisi kedua. Diterjemahkan oleh: Diah Wurjandari, Entis Sutisna dan Zulkifli Zaini. Priscilla Grace Canas-IRRI. Filipina. Hal. 96-97.

Fadli H.N., Jonathan G. dan Balonggu S. 2013. Tanggap pertumbuhan dan produksi padi gogo varietas situ bagendit terhadap pengolahan tanah dan frekuensi penyiangan yang berbeda. J Agroekoteknologi Vol. 1, No2, Maret 2013

Gardner, 1991. Fisiologi Tanaman Budidaya. UI Press: Jakarta.

Gasperz U. 2006. Teknik Analisis dalam Penelitian Percobaan Jilid 1. PT Tarsito. Bandung. 
Irianto, G. S. 2009. Peningkatan Produksi Padi Melalui IP Padi 400. Balai Besar Penelitian Tanaman Padi. Badan Penelitian dan Pengembangan Pertanian, Jakarta.

Ismunadji M., Partohardjono S., Syam M. dan Widjono A. 1988. Padi. Buku I Pusat enelitian dan Pengembangan Tanaman Pangan. Bogor.

Jamilah. 2013. Pengaruh Penyiangan Gulma dan Sistem Tanam Terhadap Pertumbuhan dan Hasil Tanaman Padi Sawah (Oryza sativa L). J Agrista Vol. 17 No.1, 2013

Jatmiko, S.Y., Harsanti S., Sarwoto, dan A.N. Ardiwinata. 2002. Apakah herbisida yang digunakan cukup aman? hlm. 337-348.DalamJ. Soejitno, I.J. Sasa, dan Hermanto (Ed.). ProsidingSeminar Nasional Membangun Sistem Produksi TanamanPangan Berwawasan Lingkungan. Pusat Penelitian dan Pengembangan Tanaman Pangan, Bogor

Karim A.M., \& Suhartatik, E. 2009. Morfologi Tanaman Padi. Balai Besar Penelitian Padi. P.295-330

Kementrian pertanian tahun 2017 produksi tanaman padi menurut provinsi

Krebs, C.J. 1989. Ecological Methodology.New York: Harper \& RowInc. Publisher.

Makarim, A. Karim dan Ikhwani. 2012. System of Rice Intensification (SRI) dan Peluang Peningkatan Produksi Padi Nasional. Pusat Penelitian dan Pengembangan Tanaman Pangan. Bogor.

Manurung, S.O. dan M. Ismunadji. 1988. Morfologi dan fisiologi padi. Dalam M. Ismunadji, S. Partohardjono, M. Syam, danA. Widjono (Ed.). Padi. Buku 1. Pusat Penelitian danPengembangan Tanaman Pangan, Bogor. hlm. 55102

Norman, .J.T., C.J Pearson, and P.G.E. Searle. 1984. The ecology of tripical food crops. CambridgeUniversity Press. Dalam Nuroktapiani, A. Pengaruh kombinasi pupuk N, P, K terhadap pertumbuhan dan hasil beberapa varietas dan galur padi (Oryza sativa L.) di lahan sawah irigasi. 2011. Universitas Singaperbangsa Karawang.

Nurhidayat. E. 2011. Pengaruh iklim terhadap produktifitas tanaman padi sawah. $\mathrm{ttp} /$ pangeranamukmarugul.blogdetik.com/2011/07/04/pengaruh-iklimterhadap-produktifitastanaman-padi-sawah/.

Odum, E. P., 1971. Dasar-Dasar Ekologi. Edisi ketiga Gadjah Mada University Press. Yogyakarta. Pusat Pendidikan Lingkungan Hidup. 2010. Pertanian Organik. Jakarta, Ricardo

Pusat Pendidikan Lingkungan Hidup. 2010. Pertanian Organik. Jakarta, Ricardo 
Soerjani, et al. 1987. Weeds of Rice in Indonesia. Balai Pustaka. Jakarta. 716 hal.

Sukman, Y dan Yakup. 2002. Gulma dan Teknik Pengendaliannya. Fakultas Pertanian Sriwijaya Palembang. Raja Grafindo Persada Jakarta.

Tjitrosoedirdjo, S., I. H. Utomo \& J. Wiroatmodjo. 1984. Pengelolaan gulma di perkebunan.Gramedia, Jakarta. 